\title{
THE PERSPECTIVES OF LONG-TERM GROWTH IN RUSSIA
}

\author{
Georgy IDRISOV - Sergey SINELNIKOV-MURYLEV
}

The paper analyses the inconsequence and problems of Russian economic policy to accelerate economic growth. The authors consider three components of growth rate (potential, Russian business cycle, and world business cycle components) and conclude that in order to pursue an effective economic policy to accelerate growth, it has to be addressed to the potential (long-run) growth component. The main ingredients of this policy are government spending restructuring and budget institutions reform, labour and capital markets reform as well as productivity growth.

Keywords: long-term economic growth, TFP, government spending restructuring, Russia

JEL classification indices: $\mathrm{H} 5, \mathrm{~J} 2, \mathrm{O} 1, \mathrm{O} 4$

Georgy Idrisov, corresponding author. Head of the Industrial Organization and Infrastructure Economics Research Center of the Russian Presidential Academy of National Economy and Public Administration, Head of the Real Sector Division of the Gaidar Institute for Economic Policy. E-mail: idrisov@iep.ru

Sergey Sinelnikov-Murylev, Professor, Rector of the Russia Foreign Trade Academy of the Ministry for Economic Development of Russia (Moscow). E-mail: sinel@vavt.ru 


\section{INTRODUCTION}

Publications in mass media and economic literature offer diverging views on what has been slowing down growth in Russia since the end of $2012^{1}$ and what should be done to cope with the downward trend. In January-December 2013 and Q4 2013, the industrial production index stood at 100.3\%, compared with the corresponding periods in $2012 .^{2}$ In the first half of 2013, investment declined by about 6\% in real terms (excluding small businesses). In 2013, state budget investments kept growing by $20-25 \%$ at current prices (as in the past), while domestic and foreign-financed private investments displayed only a 5-6\% growth in real terms, although previously, in 2011-2012, private investments displayed almost the same growth rate, about $25 \%$ annually, as budget investments did.

Since leading Russian economists and advisors to senior government officials were divided as to which budget instrument would be efficient to support and promote economic growth, there is no coherent policy in place apart from the customary "business as usual" approach. Budget expenditures did not decline in spite of the shrinking revenues, and the legally binding budget rule was simply disregarded as far as the required resource accumulation in the Reserve Fund was concerned. ${ }^{3}$ The Federal Law On the Federal Budget for 2014 and the Planning Period of 2015 and 2016 still provides for high non-productive public expenditures (public administration, law enforcement, national defence, national economy, except expenditures on infrastructure ${ }^{4}$ ) at the cost of productive expenditures on human capital (education, healthcare), science, and infrastructure.

The draft Budget Strategy until 2030, submitted in late December 2013 to the Russian Government for consideration, meets entirely the requirements for macroeconomic sustainability, although for middle term budget expenditures, it relies on state programs' expenditure caps (and only until 2020, but no budget policy priorities are specified for the period of 2021-2030) rather than expenditures in terms of budget classification. In other words, the long-term budget policy parameters - expenditures on education, healthcare, national defence, and

1 For more details about the fiscal policy role in accelerating economic growth rates, see Идрисов, Синельников-Мурылев (Idrisov - Sinelnikov-Murylev) 2013.

2 Информация о социально-экономическом положении России - 2013 г. / Росстат (Information on socio-economic situation in Russia - 2013 / Rosstat).

3 The Finance Minister stated at the Gaidar Forum in January 2014 that the Reserve Fund will be replenished with about $\mathrm{Rb} 200 \mathrm{bn}$ in 2013, however, according to our estimates, $\mathrm{Rb} 800$ $900 \mathrm{bn}$ are required to observe the budget rule. Apparently, the difference is compensation for federal budget revenue shortfall.

4 For more details, see Devarajan at al. 1997; Blankenau - Simpson 2004; IMF 1995; European Commission 2012. 
other budget sections - can hardly be discussed on the basis of this document. However, one can see some outlines of expenditure functional distribution and understand whether the trends of 2014-2016 will persist beyond the approved 3-year federal budget.

For example, expenditures on national defence are to grow up 3.1\% of GDP in 2013 to $3.9 \%$ in 2016, while their share in total expenditures will increase from 15.8 to $21.7 \%$. The overview of the Budget Strategy's parameters allows a conclusion that these expenditures will further grow to $4.3-4.4 \%$ of GDP or to $24-25 \%$ of federal budget expenditures anticipated by 2017-2020. In 2014-2016, expenditures on transport infrastructure are to be reduced by about $0.2 \%$ of GDP and fall below 1\% of GDP. In 2017-2020, these expenditures are expected to slightly increase approximately to the 2014 percent share of GDP. Expenditures on education will remain at the current prices level, declining by 2016 from 1.0 to $0.74 \%$ of GDP. Later, in 2017-2020, they are to fall a bit more in terms of GDP. Therefore, this document does not envisage a government spending restructuring as described below.

\section{POTENTIAL AND CYCLICAL COMPONENTS OF RECENT ECONOMIC GROWTH ${ }^{5}$}

For analytical purposes, it is common international practice to decompose growth rates into potential and cyclical components. Considering that the Russian economy relies heavily on global raw materials and energy markets, it is worthwhile to add to these typical components a new one that is determined by terms of trade. Simply stated, one can say that the potential of growth is a growth rate that is theoretically possible in the business cycle mid-phase, using a 15-20-year average for oil prices, and assuming the full capacity utilisation of labour and fixed assets, respectively. Table 1 presents our estimations for the Russian economy, between 1999 and 2013.

To date, global raw materials and energy market conditions have had an overall positive effect on Russia (otherwise, growth would have been negative as early as 2009-2010). On the one hand, not only high, but also steadily growing oil prices $^{6}$ pushed up Russia's real output due to growth in the oil production sector (in which incentives for greenfield oil development were created) and related sectors (the demand for intermediates of these sectors is created by the oil production

5 Durlauf et al. 2006; Rodrik 2006; Mokyr 2006; Казакова, Синельников-Мурылев (Каzаkova - Sinelnikov-Murylev) 2009.

6 Until 2012, when it stopped at \$100-110 per barrel of Brent crude oil in Europe. 
Table 1. Components of annual economic growth (GDP), \%

\begin{tabular}{l|c|c|c|c|c}
\hline \multirow{2}{*}{ Period } & $\begin{array}{c}\text { Potential } \\
\text { growth }\end{array}$ & $\begin{array}{c}\text { Cyclical } \\
\text { component }\end{array}$ & $\begin{array}{c}\text { Terms of trade } \\
\text { effect }\end{array}$ & $\begin{array}{c}\text { Total measured } \\
\text { growth }\end{array}$ & $\begin{array}{c}\text { Output gap, } \\
\text { cumulative }\end{array}$ \\
\cline { 2 - 6 } & $(1)$ & $(2)$ & $(3)$ & $(4)$ & $(1-4)$ \\
\hline $2008-2009$ & 4.5 & -13 & 1 & -7.5 & 0.4 \\
\hline 2010 & 3.4 & 0.2 & 0.9 & 4.5 & 1.5 \\
\hline 2011 & 3.0 & -0.2 & 1.5 & 4.3 & 2.7 \\
\hline 2012 & 2.6 & -0.3 & 1.1 & 3.4 & 3.6 \\
\hline 2013 & 2.2 & -1.6 & 0.7 & 1.3 & 2.7 \\
\hline 2014 & 1.4 & -1.1 & 0.3 & 0.6 & 1.0 \\
\hline 2015 (est.) & 1.1 & -2.8 & $(-1.1)-(-0.8)$ & $(-2.5)-(-2.8)$ & $(-1.7)-(-2.0)$ \\
\hline
\end{tabular}

Source: Authors' estimations.

sector or driven up by individuals with growing income). ${ }^{7}$ On the other hand, Russia's output at current prices increased, relative to that of other countries, as energy resource prices went up: GDP at PPP per capita at current prices increased from $\$ 6,800$ in 2000 to $\$ 23,500$ in 2012 , i.e. by almost 3.5 times.

In the 2000s, real output growth and a 5-fold growth in oil prices allowed Russia to move up from the lower-middle-income country group to the upperincome country group, resulting in an almost $75 \%$ increase in goods and services consumption per capita. ${ }^{8}$ It follows from the above that in 2000-2012, Russia became "wealthier" due to more favourable terms of trade not only owing to real output growth, but also because of the higher Russian-made goods value in the global market.

The Russian business cycle and structural components of growth also played a significant role in that period. In 2008-2013, however, the Russian business cycle was seriously hit by the global crisis that reinforced the overall pessimistic mood and disorientation among business people as well as the Russian economy's observers. In our interpretation, the slowdown in overall growth can be adequately explained by the "resource curse" (or Dutch Disease), whereby the rouble real exchange rate appreciation has a detrimental impact on the profitability of all

7 Quantitative estimates of this effect are presented above: this in terms of trade contribution to the Russian economic growth.

$8 \quad$ GNI at PPP per capita at 2005 constant prices, which reflects real growth in consumption and savings, increased from $\$ 8,400$ in 2000 to $\$ 14,500$ in 2012. Furthermore, consumption per capita increased from $\$ 27,300$ to $\$ 31,200$ in upper-income countries. Therefore, in 20002012 , Russia's real consumption increased by $73 \%$, while highly developed countries saw just a $16 \%$ growth. 
trade-related sectors, except mining, and the negative institutional consequences of the arising inter-sectoral imbalances. ${ }^{9}$

In the past 15 years, high wages and inefficient institutions have become the main characteristics of Russia in the international competitiveness context as a result of high raw material prices and energy resources, growth in real incomes, and the narrower gap between the rouble nominal exchange rate and purchasing power parity. ${ }^{10}$ This combination, often called the "middle-income trap", tends to hamper investment and reduce the potential for economic growth. The wage share in GDP increased (from 40\% in 2000 to $50 \%$ in 2012), while the profit share shrank (from $43 \%$ to $30 \%$ ). Growth in wages outstripped the dynamics of GDP and labour productivity. A necessary condition for getting off the trap is to increase productivity, which in turn requires labour and capital markets reforms.

Moreover, rapid growth of wages, which does not reflect growth in productivity, is heterogeneous both territorially and industrially. Local "growth points" can be easily located: Russia's central regions (first of all, Moscow), extracting sectors of the economy, and the financial service sector. Consequently, government tends to widen regulating actions, which, in turn, can distort market signals, weaken competition and delay structural changes, encourage rent-seeking strategies, promote corruption, render the public sector ineffective, and increase the unequal distribution of income and wealth. ${ }^{11}$

The described trends, typical for many countries, coupled with exhausted opportunities to involve extra labour force can seriously slow down economic growth rates. Potential economic policies aimed at accelerating economic growth can be configured using the foregoing decomposition of economic growth rates into the three components (potential/structural, Russian business cycle, and world business cycle).

The world business cycle component of growth is determined by external factors, which are beyond Russian politicians' influence. Normally, a small country cannot change the terms of trade. In many cases, the Russian business cycle component can be adjusted using a national counter-cyclical economic policy. Russia sustained no heavy social or political losses during the crisis of 2008-2009, mostly owing to the accumulated reserves, which could be used to stimulate economic development. However, neither budgetary nor monetary policies have proven efficient in the current macroeconomic situation. The budgetary policy does not work because, firstly, the existing output gap is not big enough and, secondly, its existence

$9 \quad$ For more details, see Auty 1993; Sachs - Warner 1995, 1997; Sala-i-Martin 1997; Mehlum et al. 2006; Gylfason 2007; Treisman 2010; Кнобель (Knobel) 2013.

$10 \quad$ For more details, see Griffith 2011; May (Mau) 2012, 2013; Aiyar et al. 2013.

11 Helpman 2004. 
is a necessary, but not sufficient condition for the effective stimulating policy. The budgetary policy inefficiency can be drawn by the estimates of the budget expenditures multipliers, which, according to our and other estimates, are not only small, but also less than $1 .{ }^{12}$ The expansionist monetary policy does not work because the real interest rate on loans to the nonfinancial sector ${ }^{13}$ is low and inflation is anticipated to be high and unstable. Therefore, the state only can influence the structural component of growth.

The neoclassical economic theory describes labour, capital, and their total productivity as production function factors ${ }^{14}$. However, long-term economic growth in certain countries and differences in economic development between countries cannot be explained by the difference in labour and capital only. The only way to get closer to explaining these differences is to consider their quality. ${ }^{15}$

Therefore, a long-term economic growth can be achieved through, firstly, productive investment in human capital, i.e. education (secondary, higher, lifelong, on-job), healthcare, and physical culture as well as an efficient internal and external migration policy. Secondly, sources for productive private investment in fixed capital (including consistent and predictable economic policy) should be created and public investment models have to be enhanced. Thirdly, it is important to create conditions for increasing return on private investment (total factor productivity), including increasing for budget expenditures on infrastructure and science as well as developing the policies for deeper Russian integration into the global economy.

\section{INSTITUTIONS AND INVESTMENT CLIMATE}

Institutional framework, first of all, contractual property rights (liabilities and commitments) are the most important source of long-term economic growth. ${ }^{16}$ Fixed and human capital investment, which is highly sensitive to the institutional environment quality, are the key interaction mechanisms between institutions and economic growth. Social institutions determine both the volume of resources,

12 For example, see Blanchard - Perotti 2002; Perotti 2004; Mountford - Uhling 2008; Monacelli - Perotti 2008; Giardano et al. 2008; Юдаева (Yudayeva) 2011; Дробышевский - Назаров (Drobyshevsky - Nazarov) 2012; Идрисов - Синельников-Мурылев (Idrisov - SinelnikovMurylev) 2013.

13 In 2007 and 2008, the interest rate on loans to the nonfinancial sector was negative: -2 and $-1 \%$ respectively; later, it was positive: $2 \%$ in $2010,2.3 \%$ in 2011 , and $3.2 \%$ in 2012.

14 Solow 1957; Helpman 2004; Энтов и др. (Entov et al.) 2006.

15 Barro - Sala-i-Martin 1992; Ito 2000; Helpman 2004; Isterly 2006.

16 Acemoglu et al. 2006; Энтов и др.(Entov et al.) 2006. 
which economic agents (including the state) spend on the development, and their productivity. Since the importance of reforming social institutions for the provision of long-term, steady economic growth ${ }^{17}$ has been extensively covered by both Russian and foreign literature, we will consider only a single aspect of this topic, i.e. a need for a well-defined (consistent and predictable) economic policy.

The aforementioned economic policy qualities are essential investment climate components. In practice, economic policy decisions in the Russian Federation are subject to frequent revisions, and none of the public initiatives have been completed yet. Within society, most of the recent public initiatives have come to be associated with the come-and-go style. In the 2000 s, such initiatives as the introduction of program-based planning, deregulation, introduction of performance-based budgeting, innovation promotion, "national projects" implementation, development of road maps for priority reforms (still in progress), etc., easily came into and went out of fashion.

The dubious example of the pension system. Its reform has been under way for more than a decade, beginning with the introduction of a unified social tax in 2001. Conflicting decisions were made year after year during the period: a selffunded pension contribution component was introduced for individuals of any age, then it was abolished for certain categories of older employees, and is subject to regular changes for others, ${ }^{18}$ and now it will be frozen for the period of nongovernment pension funds restructuring. At the same time, payroll rates (initially, the unified social tax and, later, social security contributions ${ }^{19}$ ) are subject to regular changes.

17 For more details see: IMF 1995; Tanzi - Zee 1997; World Bank 2006, 2007, 2013; Идрисов - Синельников-Мурылев (Idrisov - Sinelnikov-Murylev) 2013.

18 A $0 \%$ rate on the self-funded component has been established since 2002 for men born after 1952 and women born after 1956; a 2\% rate on the self-funded component was established from 2002 to 2004 for men born between 1953 and 1966, and women born between 1957 and 1966, it has been $0 \%$ since 2005; a 3\% rate was introduced from 2002 to 2003 for individuals born before 1967, a $4 \%$ from 2004 to 2007, and a 6\% from 2008 to 2013. An option to choose a defined benefit plan is available from 2014 to 2015: individuals were offered an option to retain $6 \%$ of the rate on insurance contributions to the self-funded component or give up the self-funded component, thereby allocating all insurance contributions to the PAYG pension.

19 A descending scale for the unified social tax (UST) at a $35.6 \%$ base rate was in place from 2001 to 2009 (rates for subsequent annual tax base groups of employees were $20 \%, 10 \%$, and $5 \%$, respectively, the marginal rate was reduced to $2 \%$ from $5 \%$ since 2002 , i.e. higher incomes were subject to a lower rate); since 2005 , the base rate was reduced to $26 \%$ (rates for subsequent groups stood at $10 \%$ and $2 \%$ ). In 2010, the UST was replaced with insurance contributions, without making changes to the rates and descending scale. Since 2011, the base insurance contribution rate has been raised to $34 \%$, while the contribution accrual base has been limited to $135 \%$ of average wages (that means, in fact, that a $0 \%$ marginal rate was set 
If the state had the objective to deny its citizens the opportunity to set up an individual retirement strategy, it has been accomplished with success. Individuals' credibility in that they can rely on stable "game rules" in the pension system has been totally undermined. Furthermore, none of those who developed the changes can answer the main question: what we have to do with the pension system deficit (3-4\% of GDP), which will be growing because of demographics in the decades to come (growth in the share of older beneficiaries in the total popula$\left.\operatorname{tion}^{20}\right)$ ? It therefore has to be decided which of the options are most preferable: lose $10-15 \%$ on the wage replacement rate (the current average pension to average wage ratio is approximately 35\%) while keeping the pension system deficit at the current level, or provide the wage replacement rate at $40 \%$ while increasing the deficit to $5 \%$ of GDP by 2020 ?

The Russian government has recently started the parametrical reform set to introduce a new pension formula. ${ }^{21}$ The new policies have had no drastic effects: according to our estimates, by 2030, the pension system deficit will fall to $2 \%$ of GDP, while the wage replacement rate decline by $15 \%$. By and large, these policies are headed in the right direction, but they cannot fully resolve the pension system deficit issue, which can be done either by raising the retirement age or by reducing the wage replacement rate, or introducing an age-specific partial pension differentiation (replacement rate). However, the suggested nearly age-equalised reduction in the replacement rate, without raising the retirement age, is not the best option because individuals who are not able to work (older beneficiaries) and those who are still able to work (individuals aged 60-65, not to mention early retirees) will then be entitled to pension. This is not a reliable approach to older beneficiaries who do need more money for a normal life.

There are more essential issues that need to be addressed in order to develop a coherent pension system reform. For example, it is questionable whether there is a need for a public pension savings system whereby the state collects and saves individuals' contributions while borrowing in financial markets. There is a solid argument that favours this system: it is much easier to manage self-funded component contributions than taxes because individuals have a different attitude to-

for the second annual tax base groups). Thereafter, a decision was made to reduce the base rate to $30 \%$ for the first group and increase it to $10 \%$ for the second one (a 10\% marginal rate was set instead of 0\%) in 2012-2016. Currently, the Pension Fund deficit incurred from the lower rate implementation is financed by federal budget transfers.

20 Rosstat's average scenario for demographic projection until 2030 shows that the share of persons beyond the working age in the total population will increase from $23 \%$ in 2013 to $26 \%$ in 2020 and $29 \%$ in 2030 (at the beginning of the year). www.gks.ru/free_doc/new_site/ population/demo/progn3.htm.

21 The Council of Federation approved a new pension formula in late December 2013. 
wards saving self-funded pension versus paying taxes within the PAYG scheme. However, this hypothesis has to be tested empirically, plus the theory describes the taxpayers' myopia effect. Another argument in favour of the public pension savings system is the creation of a "long money" source for investment. However, it should be remembered that the self-funded scheme requires high administrative costs versus the PAYG scheme, plus the former may lead to potential losses from macroeconomic fluctuations.

Additionally, it is important to consider a long-term transformation of the pension system into a poverty benefit system whereby the entitlement to public pension must be means-tested. Needless to say, this is still a long way in the future, when growth in well-being will allow most individuals to live without the public pension system and reach an appropriate consumption level in old age through sufficient personal savings, including those in non-governmental pension funds, and help from their working age family members. Furthermore, working beneficiaries' entitlement to pension is another issue which is worth considering. There is an important side issue: whether individuals' contributions from the self-funded scheme should be inheritable or whether the pension system should rely on the insurance-based principles of risk sharing? Clearly, inheritance tends to increase propensity to save; however, the self-funded scheme is easier to administer and more cost efficient within the insurance-based pension system.

Restructuring in higher education. Another good illustration of inconsistent and unpredictable economic policy is public sector restructuring and per capita financing for social service provision. Reforms in this sector were intended to restructure the budget-funded entities network, enhance the self-dependence of organisations, and introduce a kind of competition based on the "budget money follows the recipient" principle.

In practice, however, nothing has been done in the context of the meaningful restructuring of the budget-funded entities network; the entities needed by the country are facing economic "erosion" due to the lack of funding. Regulatory control over autonomous institutions has been actually mixed with budget-funded entities regulation; the income and expenditure budget through which entities are funded has been transformed into a business plan. Funding standards, especially in higher education, are applied mostly for allocating less public funds to strong entities and more to weak ones, without undertaking any reforms. ${ }^{22}$

In his report to the Duma, the Minister of Education and Science spoke against raising wages in higher education institutions without increasing the teachers' workload. President Putin has been representing the same opinion since 2009.

22 Клячко - Синельников-Мурылев (Klyachko - Sinelnikov-Murylev 2012a, 2012b). 
Nevertheless, the Ministry of Education and Science, as well as the Ministry of Finance try, by freely interpreting the legislation, ${ }^{23}$ to increase the tuition fees for off-budget students to a level equal to or higher than the amount the central budget pays after regular, state-supported students. ${ }^{24}$ Under the Presidential Decree of May 7, 2012, staff salaries in higher education must be twice as much as the average regional wages. However, the introduction of unified standards for public funding to universities ignores the wage differences among regions. There is no country whose government spends public resources to purchase education services at a unified price (which covers all current and capital costs). The per-student funding standard is an essential but not the only financial planning instrument.

As a result of such confusion, it is not senior government officials, but the low-level bureaucrats in the ministries who make the decisions on how many and which type of social services Russia needs. What we showed for the higher education sector applies to other areas of the social services, too. This demonstrates, in our opinion, the total absence of the public sector reform concept.

Therefore, the sequence and stages of reforms in higher education should be developed, tested, discussed, and approved at the top political level. Attempts to introduce a normative per capita financing are doomed to failure if no preliminary higher education institutions network restructuring is performed. The network and funding volumes cannot be changed without addressing the issue of whether the Russian economy really needs so-called inefficient and/or lowdemand higher education institutions. It is obvious that the economy needs mechanical engineers, textile workers, water supply, drainage and sewage engineers, agriculturalists, veterinaries, hydrometeorologists as well as skilled workers of various occupations, etc. Education should therefore be financed on the detailed forecast basis of the economic demand for such a labour force. To avoid substantial dynamic welfare losses, this task should not be left to "the invisible hand of the market". It is important to figure out what to do with inefficient higher education institutions, i.e. let them degrade slowly by reducing their funding (as currently), or shut them down to open new ones, or replace their top managers and allocate extra funding to facilitate the recovery of the institutions.

23 In our opinion, Article 9.2 of the Federal Law No.7-FZ of January 12, 1996 (as amended on 01.09.2013) On the Provision of Budget Services by an Organization on Equal Terms for Recipients speaks against price discrimination of consumers; the state does not buy educational services, but basically provides funding to the social sector when it (the state) allocates funds to an entity based on per student standard.

24 Клячко - Синельников-Мурылев (Klyachko - Sinelnikov-Murylev) 2012 b. 


\section{PRIMARY TASKS FOR ECONOMIC POLICY}

\section{Government spending}

It is known that growth rates in countries whose budget expenditure structure is similar to that in Russia will never be sufficient for catching-up development, i.e. for growth rates convergence with developed countries, not to mention economic development levels convergence. ${ }^{25}$ Unlike investment in fixed capital, in which the state's task is to provide the institutional framework required for private investment, it (the state) plays the dominant role in the human capital and infrastructure development. The economic theory holds that "market failures" may occur in response to substantial externalities and that without public regulation and substantial investment, the market cannot provide a socially optimal volume of education, healthcare, and R\&D.

Budget-funded entities should further be developed within the public investment model framework. Investment decisions should be based on the maintenance and operation costs of established facilities. It is important to switch investment project financing from a phase-by-phase scheme instead of connecting financing to fixed time schedules. A network of non-strategic public enterprises which significantly distort market conditions needs to be reorganised, including gradual finance cutting for loss-making enterprises with state share in capital.

Making gradual changes in revenue-side budgeting which relies heavily on oil and gas revenues should be focused on as essential policy aimed at reducing inappropriate subsidies to the economy. Nowadays, the existence of export duties to collect resource rent leads to lower energy resource prices. As a result, subsidies to the economy amount to about $4 \%$ of GDP. ${ }^{26}$ Furthermore, our analysis shows that it is not the competitive product manufacturing that is promoted and neither are end-use consumers subsidised; rather it is manufacturers' ineffectiveness that is defrayed, primarily in crude oil refinement, using negative value added (in world prices terms) technologies.

Unfortunately, the recent changes in the structure of public expenditures cannot be regarded conducive to long-term economic growth.

The foregoing considerations seem to provide sufficient grounds for the changes to the public expenditure structure to be viewed as the main trend of the long-term fiscal policy. This can be done through the government spending re-

25 Barro - Sala-i-Martin 1992; Гайдар (Gaidar) 2005; Дробышевский и др. (Drobyshevsky et al.) 2011; Кнобель - Соколов (Knobel - Sokolov) 2012; Идрисов - Синельников-Мурылев (Idrisov - Sinelnikov-Murylev) 2013.

26 Идрисов - Синельников-Мурылев (Idrisov - Sinelnikov-Murylev) 2012. 
structuring in fiscal policy, i.e. the reallocation of public expenditures from budget sections - national defence, law enforcement, public administration - which cannot or ineffectively facilitate economic growth (beyond a certain limit) in favour of those - education, healthcare, infrastructure - which can promote growth. Spending in these sectors cannot be interpreted as socially required expenses or as a supplement to the social services provision - rather they should be viewed as investment in a long-term economic growth.

Table 2. Changes in public expenditures in percent of GDP

\begin{tabular}{l|c|c|c|c}
\hline & $2007-2011$ & 2012 & 2013 & 2014 \\
\hline National defence & 2.7 & 2.9 & 3.2 & 3.5 \\
\hline National security and law enforcement & 2.8 & 3.1 & 3.2 & 3.1 \\
\hline Education & 4.2 & 4.2 & 4.3 & 4.3 \\
\hline Health care & 3.8 & 3.7 & 3.5 & 3.5 \\
\hline $\begin{array}{l}\text { National economy } \\
\text { (including transport and infrastructure) }\end{array}$ & 5.5 & 5.3 & 4.9 & 6.4 \\
\hline
\end{tabular}

Source: The Federal Treasury, http://www.roskazna.ru/

It needs to be noted that this government spending restructuring in favour of productive expenditures may encounter serious constraints: it has to be done in the face of general government expenditures cut as share of GDP, which is very painful politically. However, economic growth at current prices can be used and productive expenditures can be increased while maintaining the current level of non-productive expenditures. ${ }^{27}$

\section{Labour markets}

In our view, the first task should be to develop a new employment strategy and wage optimisation in the public sector (eliminating distortions caused by accelerated wage growth). There is a need to make the labour market more flexible, and to prepare the concept of and adopt a new Labour Code. Changes to the labour relation regulations should be focused on making employee-employer relations more flexible through extensive use of fixed-term contracts, simplified staff recruitment and dismissal procedures, substantially expanded grounds for fixed-

27 With real GDP annual growth rates at 2\% and GDP deflator (price growth) at about $4 \%$, real non-productive expenditures can be reduced by $3 \%$ of GDP, while productive expenditures can be increased by the same percentage of GDP within 4-6 years, without increasing nonproductive public expenditures at current prices. 
term labour contracting, simplified procedures for changing labour contract terms and terminating the same due to economic reasons, efficient procedures for revising wages facing an economic turbulence, and simplified HR procedures.

It is important to reduce informal employment, including introduction of simplified taxation schemes for micro-sized enterprises and self-employed individuals. Information transparency in the labour market should be enhanced by developing a market valuation system and market development assessment prospects, including specific market segments, as well as creating an efficient and accessible system whereby employers, employees, and education institutions can receive quantitative information and qualitative characteristics of the labour demand and supply. Growing adverse demographic trends (skilled labour force outflow accelerates as young labour force inflow slows down) should be tackled through policies which can enhance substantially the potential and scale of cross-region and cross-country labour mobility, and the reemployment of the inefficiently used labour force from the defence, law enforcement, and public administration sectors.

\section{Capital markets}

The country needs government policies supporting small and medium-sized entrepreneurship. It is important to mitigate business risks associated with unlawful business activity suspension for formal reasons (by regulatory and law enforcement authorities) and to ease the regulatory burden on business entities as well as unnecessary burdens arising from wrong incentives for public agencies to exercise enforcement (the existing legal framework requires that regulatory and supervisory authorities initiate legal proceedings, impose fines and penalties, etc., without taking into consideration the validity and consequences of such actions). Additionally, the anti-monopoly policy and regulation of natural monopolies should be improved, which also includes an institutional reform of the Federal Anti-Monopoly Service (FAMS) and the Federal Tariff Service (FTS).

Measures aimed at improving Russia's ranking in Doing Business should become an explicit priority. There are areas covered by Doing Business in which Russia stands low in the ranking (e.g., below 100th in the ranking of economies), which should be improved as a matter of priority. The areas are the ease of "dealing with construction permits", "getting electricity", "getting credit", "protecting investors", and "trading across borders". To do this, Russian best practices can be introduced in all regions of the Russian Federation. ${ }^{28}$

28 Russia's ranking in Doing Business is counted using Moscow city performance. Our estimates show that Russia will improve ranking from 92nd to 64th by employing the Russian best practices (that are in place in the other regions) in Moscow alone. 
An essential policy of developing small and medium-sized business would be the establishment of a "credit factory" (a simplified lending system to small and medium-sized enterprises), which could refinance loans, provide guarantees on loans, and issue subsidies for partial interest rate compensation. ${ }^{29}$ The above listed polices will help improve investment climate at least in the mid-run perspective and allow productive capital to be efficiently involved in the economy.

\section{Productivity}

We deem the following changes promising:

(i) corporate cost moderation (primarily in natural monopoly sectors);

(ii) liberalising sectors which by nature are not natural monopolies (communication services, heat-and-power engineering, certain seaport services);

(iii) more resources channelled to transport and social infrastructures development in order to eliminate bottlenecks;

(iv) exploiting efficient forms of private-public partnership.

It is important to continue Russia's integration into the global economy, thereby enhancing production efficiency by improving recourse allocation and revealing Russian manufacturers' comparative advantages. This implies overall external trade liberalisation, including tariff and non-tariff barriers reduction, and simplified export and import procedures. It is important to develop policies making the Russian economy less sensitive to raw materials market fluctuations through its diversification, including the development of WTO non-actionable instruments for manufacturing industries support. It is therefore important to define priorities and targets for the non-mineral export development, and to provide it with organisational, informational and financial support.

Finally, it is worth noting that a positive institutional reform program should be elaborated because none of the recent public initiatives have been implemented up to the final stage. It is important to consider all pros and cons, identify the most efficient instruments for accomplishing the set goals, and ensure that a strict progress monitoring is in place.

29 It is noteworthy that on February 5, 2014, the Russian Government approved the establishment of the Loan Guarantee Agency. 


\section{REFERENCES}

Гайдар E.T. (2005): Долгое время. Россия в мире: очерки экономической истории. 3 -е изд (Gaidar, E.T.: Russia: A Long View.) Moscow: Delo. http://ideas.repec.org/b/mtp/titles/0262017415. html

Дробышевский C. - Назаров П. (2012): Оценка бюджетного и налогового мультипликатора в Российской Федерации (Drobyshevsky, S. - Nazarov, P.: Theoretical Aspects of the Evaluation Budget Multiplier in Russia). Moscow: RANEPA. Mimeo. http://papers.ssrn.com/sol3/ papers.cfm?abstract_id $=2341347$

Дробышевский С. - Синельников-Мурылев С. - Соколов И. (2011): Эволюция бюджетной политики России в 2000-е годы: в поисках финансовой устойчивости национальной бюджетной системы. Вопросы экономики, № 1. С. 4-25 (Drobyshevsky, S. - SinelnikovMurylev, S. - Sokolov, I.: Transformation of Budgetary Policy in Russia during the 2000s: In Quest of National Fiscal Sustainability). http://ideas.repec.org/a/nos/voprec/2011-01-1.html; http://papers.ssrn.com/sol3/papers.cfm?abstract_id $=2170808$

Идрисов Г. - Синельников-Мурылев Г. (2012): Модернизация или консервация: роль экспортной пошлины на нефть и нефтепродукты. Экономическая политика, № 3. C. 5-19 (Idrisov, G. - Sinelnikov-Murylev, S.: Modernization or Conservation: The Role of Export Duty on Crude Oil and Petroleum Products). http://ideas.repec.org/p/gai/wpaper/0042.html; http:// papers.ssrn.com/sol3/papers.cfm?abstract_id $=2165179$

Идрисов Г. - Синельников-Мурылев С. (2013): Бюджетная политика и экономический рост. Вопросы экономики, № 8. С. 35-59 (Idrisov G. - Sinelnikov-Murylev, S.: Budget Policy and Economic Growth). http://ideas.repec.org/p/gai/wpaper/0076.html; http://papers.ssrn.com/sol3/ papers.cfm?abstract_id $=2367933$

Казакова М.В. - Синельников-Мурылев С.Г. (2009): Конъюнктура мирового рынка энергоносителей и темпы экономического роста в России. Экономическая политика, № 5. С. 118-135 (Kazakova, M. - Sinelnikov-Murylev, S.: The Global Market for Energy Sources and the Pace of Economic Growth in Russia). http://ideas.repec.org/p/gai/wpaper/0003.html; http:// papers.ssrn.com/sol3/papers.cfm?abstract_id $=2112009$

Клячко T. - Синельников-Мурылев С. (2012а): О реформировании системы финансирования вузов. Вопросы экономики, № 7. С. 133-146 (Klyachko, T. - Sinelnikov-Murylev, S.: On the Financial Reform in Russia's Higher Education). http://ideas.repec.org/p/gai/wpaper/0052. html; http://papers.ssrn.com/sol3/papers.cfm?abstract_id=2223866

Клячко T. - Синельников-Мурылев С. (2012b): О нормативах бюджетного финансирования и регулирования величины платы за обучение в государственных вузах. Экономическая политика, № 6. C. 137-164 (Klyachko, T. - Sinelnikov-Murylev, S.: On Standards of Budget Funding and Adjusting the Fees in State Universities). http://ideas.repec.org/p/gai/wpaper/0072. html; http://papers.ssrn.com/sol3/papers.cfm?abstract_id=2354229

Кнобель А. (2013): Риски бюджетной политики в странах, богатых природными ресурсами. Экономическая политика, № 5. С. 29-38 (Knobel, A.: The Risks of Fiscal Policy in Countries Rich in Natural Resources). http://papers.ssrn.com/sol3/papers.cfm?abstract_id=2362818

Кнобель А. - Соколов И. (2012): Оценка бюджетной политики РФ на среднесрочную перспективу. Экономическое развитие России, № 12 (19): С. 23-32 (Knobel, A. - Sokolov, I.: Assessment of Russian Budget Policy System in the Medium Term Perspective).

May B. (2012): Экономика и политика в 2011 году: глобальный кризис и поиск новой модели роста. Bопросы экономики, № 2. C. 4-26 (Mau, V.: Economics and Politics in 2011: The Global Crisis and the Quest for a New Growth Model). http://ideas.repec.org/p/gai/ppaper/9. html; http://papers.ssrn.com/sol3/papers.cfm?abstract_id=2117752 
May B. (2013): Между модернизацией и застоем: экономическая политика 2012 года. Boпросы экономики, № 2. C.4-23 (Mau, V.: Between Modernization and Stagnation. Russian Economic Policy and Global Crisis). http://ideas.repec.org/p/gai/wpaper/0057.html; http://papers.ssrn. com/sol3/papers.cfm?abstract_id $=2230355$

Энтов Р. - Радыгин А. - Межераупс И. - Швецов П. (2006): Корпоративное управление и саморегулирование в системе институииональных изменений. М.: ИЭПП. www.iep.ru. (Entov, R. - Radygin, A. - Mezheraups, I. - Shvetsov, P.: Corporate Governance and Self-Regulation in Institutional Changes System). Moscow: IEP. http://ideas.repec.org/a/gai/rpaper/104. html.

Юдаева К. (2011): Эффективность госрасходов в России. Обзор Центра макроэкономических исследований Сбербанка России (Yudaeva, K.: Government Spending Efficiency in Russia). Moscow: Review of the Center for Macroeconomic Studies, Sberbank.

Acemoglu, D. - Johnson, S. - Robinson, J.A. (2006): Institutions as the Fundamental Cause of Long-Run Growth. Handbook of Economic Growth. North Holland: Elsevier.

Aiyar, S. - Duval, R. - Puy, D. - Wu, Y. - Zhang, L. (2013): Growth Slowdowns and the MiddleIncome Trap. IMF Working Paper, No. WP/13/71.

Auty, R. (1993): Sustaining Development in Mineral Economies: The Resource Curse Thesis. London - New York: Routledge.

Barro, R. - Sala-i-Martin, X. (1992): Convergence. Journal of Political Economy, 100: 223-258.

Blanchard, O. - Perotti, R. (2002): An Empirical Characterization of the Dynamic Effects of Changes in Government Spending and Taxes on Output. The Quarterly Journal of Economics, 117(4): 1329-1368.

Blankenau, W.F. - Simpson, N.B. (2004): Public Education Expenditures and Growth. Journal of Development Economics, 73(2): 583-605.

Devarajan, S. - Swaroop, V. - Zou, H. (1997): The Composition of Public Expenditure and Economic Growth. Journal of Monetary Economics, 37: 313-344.

Durlauf, S. - Johnson, P. - Temple, J. (2006): Growth Econometrics. Handbook of Economic Growth. North Holland: Elsevier.

Easterly, W.R. (2006): The Elusive Quest for Growth: Economists'Adventures and Misadventures in the Tropics. Moscow: Institute for Complex Strategic Studies.

European Commission (2012): The Quality of Public Expenditures in the EU. European Economy. Occasional Papers, No. 125.

Giordano, R. - Momigliano, S. - Neri, S. - Perotti, R. (2008): The Effects of Fiscal Policy in Italy: Evidence from a VAR Model. Banca d'Italia Working Papers, January.

Giorno, C. - Richardson, P. - Roseveare, D. - van der Noord, P. (1995): Estimating Potential Output, Output Gaps and Structural Budget Balances. OECD Economics Department Working Papers, No. 152 (www.oecd.org/dataoecd/2/43/33928808.pdf).

Gylfason, T. (2007): The International Economics of Natural Resources and Growth. Minerals and Energy, 22(1-2): 7-17.

Helpman, E. (2004): The Mystery of Economic Growth. Harvard University Press.

IMF (1995): Unproductive Public Expenditures: A Pragmatic Approach to Policy Analysis. IMF Pamphlet Series, No. 48.

Ito, T. (2000): Perspectives on Asian Economic Growth: Neoclassical Growth vs. Flying Geese Growth. In: Ito, T. - Sonobe, T. - Shibata, A. - Fukao, K. (eds): East Asian Economic Growth with Structural Change: Neoclassical Growth Theory vs. Flying Geese Pattern. Tokyo: Economic Research Institute.

Mehlum, H. - Moene, K. - Torvik, R. (2006): Institutions and the Resource Curse. The Economic Journal, 116(508): 1-20. 
Mokyr, J. (2006): Long-Term Economic Growth and the History of Technology. Handbook of Economic Growth. North Holland: Elsevier.

Monacelli, T. - Perotti, R. (2008): Fiscal Policy, Wealth Effect and Markups. NBER Working Papers, No. 14584.

Mountford, A. - Uhlig, H. (2008): What Are the Effects of Fiscal Policy Shocks? NBER Working Papers, No. 14551.

Moreno-Dodson, B. (ed.) (2013): Is Fiscal Policy the Answer? A Developing Country Perspective. Washington, D.C.: World Bank.

Nallari, R. - Yusuf, Sh. - Griffith, B. - Bhattacharya, R. (eds): (2011): Middle-Income Trap. Frontiers in Development Policy. Washington, D.C.: World Bank.

Perotti, R. (2004): Estimating the Effects of Fiscal Policy in OECD Countries. University Bocconi and Centre for Economic Policy Research (IGIER), March.

Rodrik, D. (2006): Growth Strategies. Handbook of Economic Growth. North Holland: Elsevier.

Sachs, J.D. - Warner, A.M. (1995): Natural Resource Abundance and Economic Growth. NBER Working Papers, No. 5398.

Sachs, J.D. - Warner, A.M. (1997): Fundamental Sources of LongRun Growth. American Economic Review, 87(2): 184-188.

Sala-i-Martin, X.X. (1997): I Just Ran Two Million Regressions. American Economic Review, 87(2): $178-183$.

Solow, R. (1957): Technical Change and Aggregate Production Function. Review of Economics and Statistics, 39: 312-320.

Treisman, D. (2010): Is Russia Cursed by Oil? Journal of International Affairs, 63(2): 85-102.

Tanzi, V. - Zee, H. (1997): Fiscal Policy and Long Run Growth. IMF Staff Papers, 44(2): 179209.

World Bank (2006): Fiscal Policy for Growth and Development: An Interim Report. Background Paper for the Development Committee Meetings.

World Bank (2007): Fiscal Policy for Growth and Development: Further Analysis and Lessons from Country Case Studies. Background Paper for the Development Committee Meetings. 